\title{
VII. The beats of mistuned consonances
}

\section{Professor Silvanus P. Thompson B.A. D.Sc.}

To cite this article: Professor Silvanus P. Thompson B.A. D.Sc. (1882) VII. The beats of mistuned consonances, Philosophical Magazine Series 5, 13:78, 68-70, DOI: 10.1080/14786448208627144

To link to this article: http://dx.doi.org/10.1080/14786448208627144

$$
\text { 曲 Published online: } 28 \text { Apr } 2009 .
$$

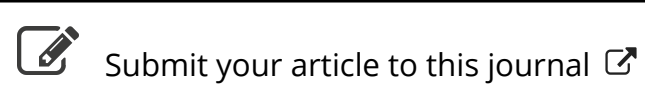

Џلl Article views: 2

Q View related articles ¿ 


\section{[ 68 ]}

VII. The Beats of Mistuned Consonances. By Professor Silvanus P. Thompson, B.A., D.Sc.

To the Editors of the Philosophical Magazine and Journal. GenTLenew,

TN a letter published in your December Number Mr. Bosan1 quet laments that his labours upon the beats of mistuned consonances bave been thrown away upon me, because I have ventured to criticise two points in bis valuable and interesting researches.

These points are, first, his misuse of the word "subjective" as applied to the phenomena in question; and, second, the priority of Dr. König in the analysis of the phenomenon so far as it can yet be said to be analyzed, to the credit of which Mr. Bosanquet lays a direct clain.

I will deal with Mr. Bosanquet's objections separately, merely observing that it would indeed be a pity if " the credit" of any discovery to which Mr. Bosanquet is entitled could be " taken away by a careless sentence" of mine.

Mr. Bosanquet's attempt to defend his use of the word "subjective," as applied to the difference-tones or beat-notes, is virtually an admission of the very point for which I contend. By way of defence, he retires behind the shelter of Helmholtz and of Mr. Ellis, who, it appears, have lapsed into the same laxity of language. On reading Mr. Bosanquet's reference to Helmholtz, I immediately turned to p. 234 of Ellis's translation (the only edition at hand at the moment), and found that I had underlined the word in pencil, and had added in the margin " sic" by way of protest. But whether Mr. Bosanquet sins in good company or not, I am still of opinion that it is unwarrantable to apply the term "subjective" to that which has a physical existence independently of the conscious "ego," or of the brain through which consciousness works. The ear is, as I have said elsewhere, only a complex resonator; and any other suitable resonator will also respond to the tones in question, provided it possesses the asymmetry of its parts which is necessary for the development of those tones. To speak of such tones as subjective is a palpable abuse of the term. But I really do not require to insist further on this point if, as Mr. Bosanquet says, he does not believe " much" in the "advancement of clearness by the employment of words very strictly defined."

Secondly, as to König's priority in the observation that the beats of imperfect consonances consist of variations in the intensity of the lower of the two tones. This observation Mr. Bosanquet says was "unquestionably" first obtained by him- 
self. For Mr. Bosanquet's sake I regret that the tone of his letter leaves me no alternative but to produce the evidence upon which I deliberately assigned priority to Dr. König.

Mr. Bosanquet appears to have read König's papers ; for he says he "knew" them "intimately," and that "there was no vestige of guidance in them on the subject;" that "König never analyzed his beats, and never enunciated any opinion whatever as to the notes of whose variation the beats consist, except in the one case of the octave.... where he says that fundamental and octave are heard alternately."

There lie before me at this moment the Annalen of Poggendorff for the year 1876 (Bd. clvii.) It is true that Konig states therein that the two primaries are alternately heard; but that he traced this alternation to its true cause is shown by the very paragraph in which this statement occurs. I quote from p. 188 of the volume of the Annalen, italicizing the words which Mr. Bosanquet appears to bave overlooked when he says that König did not analyze or enunciate any opinion, and that König only touched the case of the octave.

" Eine Eigenthümlichkeit der Stösse harmonischer Intervalle besteht noch darin, das die beiden primären Töne abwechselnd hervortreten. Lässt man neben dem starken, grossen $C$ das nur um einen geringen Theil einer Schwingung verstimmte kleine $c$ ertönen, so dass sich sehr langsame Stösse bilden, so hört man abwechselnd einmal den Grundton und einmal die Octave so deutlich hervortreten, dass man, wenn das kleine $c$ sehr stark ist, mitunter geneigt seyn könnte, jede Schwebung doppelt zu zählen. Ist das kleine c dagegen schwach, so hört man nur den Grundton abwechselnd stärker und schwächer werden. Ganz dieselbe Beobachtung habe ich auch bei den sehr langsamen Stössen der Duodecime, und der Doppeloctave, $C: g$ und $C: c^{\prime}$ machen können, aber bei nur einigermassen schnellen Schwebungen lässt sich das periodische Hervortreten des höberen Tones nicht mehr wahrnehmen."

It is the more remarkable that König's insight into the cause of the alternation mentioned in the first sentence of the paragraph quoted above should have escaped Mr. Bosanquet's notice, since three months before the publication of Mr. Bosanquet's paper in the Philosophical Magazine König had published another very important paper in Wiedemann's Annalen (Bd. xii. 1881, p. 337), in which the results of a reexaminatian of the very point in question are most unequivocally laid down. I quote the passage from p. 341, again italicizing the important words.

"Regulirt man ferner die Intensität der beiden Töne eines alterirten harmonischen Intervalls in der Weise, dass die Stösse am deutlichsten hervortreten, so müssten, wenn sie durch den höheren primären Ton und einen im Ohre erzeugten harmonischen Oberton 
des tieferen, also durch zwei Töne im Einklang gebildet wären, diese Stösse auch auf diesen Oberton gehört werden, man nimmt aber gerade das Gegentheil wahr, d. h. das der Grundton seine, Intensität periodisch ändert und dabei nur in den Momenten grösster Schwächung den höheren Ton hervortreten lässt, wie ich frïher beschrieben."

With Mr. Bosanquet's permission, I will translate the words in which Dr. König states what he observes, namely that " the fundamental tone alters its intensity periodically, and thereby allows the higher tone to come out only in the moments of greatest enfeeblement, as I formerly described.

I will leave to your readers to decide whother the alleged injustice of my "careless sentence" is objective or subjective in character; or whether credit for discovery is one of those terms in the strict definition of which we are not to believe "much." I remain, Gentlemen, .

Yours faithfully.

University College, Bristol, Silvanus P. Thompson. December 19th, 1881 .

VIII. Proceedings of Learned Societies.

GEOLOGICAL SOCIETY.

[Continued from vol. xii. p. 75.]

November 2, 1881.-Robert Etheridge, Esq., F.R.S., President, in the Chair.

TTHE following communications were read:-

1. "On the Genus Stoliczkaria, Dunc., and its Distinctness from Parkeria, Carp. and Brady." By Prof. P. Martin Duncan, M.B. Lond., F.R.S., F.G.S., Pres. R.M.S.

2. "On the Elasticity- and Strength-constants of Japanese Rocks." By Thomas Gray, Esq., B.Sc., F.R.S.E., and John Milne, Esq., F.G.S.

In this paper the authors described the results of some experiments made to determine the elasticity-constants and strength against rupture and crushing of a few of the commoner Japanese rocks, their chief object being to obtain data for calculating the theoretical velocities of earthquake-wave transmission. The rocks submitted to experiment were a grey granite, a pure white crystalline marble, a greyish-green soft tuff, a mottled clay-rock, and clayslate.

Young's moduli were determined by the bending of solid cylinders of the rocks in an apparatus described and figured; the deviatinns produced were read by means of the reflection from a mirror, which magnified them more than 200 times. The process for determining the rigidity was also described and illustrated by a figure; and the experiments in crushing were made upon columns of stone by means of a Bramah press. In experiments on the 